\section{REFERENCES}

Acred, P., Brown, M., Turner, D. H., and Wilson, M. J. (1962): Brit. J. Pharmacol., 18, 356.

Auhagen, E., Gloxhuber, Ch., Hecht, G., Knott, Th., Otten, H., Rauenbusch, E., Risse, K. H., Schmid, J., Scholtan, W., and Walter, A. M. (1962): Arzneimittel-Forsch, 12, 791.

Barber, M., and Waterworth, P. M. (1962) $\vdots$ Brit. med. J., i, 1159.

Brumfitt, W., Percival, A., and Carter, M. J. (1962): Lancet, i, 130.

BunN, P. A.: Antimicrobial Agents and Chemotherapy-1962, p. 739, Amer. Soc. Microbiol.

Daikos, G. K., Kontomichalou, P., and Paradelis, A. (1963): Dtsch. med. Wschr., 88, 1678.

EDITORIAL (1961): Brit. med. J., ii, 574.

GARROD, L. P.. (1960): Brit. med. J., i, 527.

Garrod, L. P. (1960): Brit. med. J., ii, 1695.

KNudsen, E. T., Rolinson, G. N., and Stevens, S:. (1961): ibid, ii, 198.

Naumann, P. (1962): Arzneimittel-Forsch., 12, 984.
Naumann, P. (1963): Dtsch. med. Wschr., 88, 165.

NaumanN, P. (1964): Proceedings of IIIrd Internat. Congress of Chemotherapy, Stuttgart, 1963. Stuttgart: Georg Thieme-Verlag. In the press.

Rolinson, G. N., and Stevens, Sh. (1961): Brit. med. J., ii, 191.

Rolinson, G. N. (1964): Proceedings of IIIrd Internat. Congress of Chemotherapy, Stuttgart, 1963. Stuttgart: Georg Thieme-Verlag. In the press.

Rutenburg, A. M., Greenberg, H. L., SchWeinburg. F. B., and Perreault, M. A.: Antimicrobial Agents and Chemotherapy, 1962, p. 748, Amer. Soc. Microbiol.

SöKELAND, J. (1964): Proceedings of IIIrd Internat. Congress of Chemotherapy, Stuttgart, 1963. Stuttgart: Georg Thieme-Verlag. In the press. Stewart, G. T., Coles, H. M. T., NixoN, H. H., and Holt, R. J. (1961): Brit. med. J., ii, 200.

Trafford, J. A. P., Mclaren, D. M., Lillicrap, D. A., Barnes, R. D. S., Houston, J. C., and KNOX, R. (1962): Lancet, i, 987.

\title{
AMPICILLIN AND SULPHADIMIDINE IN TREATMENT OF URINARY TRACT INFECTION
}

\author{
J. C. Gould and Elizabeth EDMond
}

Central Microbiological Laboratories, Edinburgh, 4.

From the bacteriological point of view there is a great difference between the "primary" case of urinary tract infection such as occurs in the young adult with bacteriuria, and the "secondary" or chronic case such as the chronic pyelonephritic who has had much investigation and treatment. In the former the flora is almost invariably simple consisting of Esch. coli; in the latter the flora is frequently complex and many of the infecting strains are resistant to the antibacterial agents commonly used in treatment. The treatment of such cases is less satisfactory, particularly with the sulphonamides.

The primary type of case is however important since successful treatment of such early cases should reduce the incidence of chronic infection. It is important that these early cases be treated effectively to eradicate the infection before irreversible damage has been caused to renal tissue and chronic pyelonephritis becomes inevitable.

The general practitioner and the obstetrician most frequently come into contact with this type of early case. Many use sulphonamides in the treatment of infections of the urinary tract with good results, and since sulphonamides are relatively cheap and familiar to them they tend to be the drugs most frequently used. Some workers have suggested that these results are more apparent than real, and failure to eradicate the infection leads to relapse and the development of chronic disease.

\section{Diagnosis}

The diagnosis of urinary tract infection is particularly important in the young woman, for in our opinion there are more such women treated for non-existent urinary tract infection than who fail to have treatment for an infection which has not been diagnosed. Important in this context is a proper appreciation of quantity and quality of the urinary microflora and the examination of the urine by the bacteriologist should involve an assessment of the following factors:

1. Serial specimens of urine must be examined before treatment to establish that a significant bacteriuria exists. In a number of patients intermittent bacteriuria may lead to 
TABLE I

Types of Bacteria

\begin{tabular}{cccc}
\hline $\begin{array}{l}\text { No. of } \\
\text { strains }\end{array}$ & Esch. coli & $\begin{array}{c}\text { N.L.F.* } \\
\text { Ex. Proteus } \\
\text { and } \\
\text { aseudomonas }\end{array}$ & Enterococcus \\
55 & & $\begin{array}{c}10 \\
(74 \%)\end{array}$ & 4 \\
& $(19 \%)$ & $(7 \%)$ \\
\hline
\end{tabular}

Number of patients examined 893

Number with significant bacteriuria 55 (6.2\%)

${ }^{*}$ N.L.F. $=$ non-lactose fermenting coliform bacilli.

false negative results.

2. A quantitative estimation of viable bacteria present in the urine to the order of ten.

3. A full qualitative assessment of the flora isolated. In cases of significant bacteriuria the pathogens outnumber the contaminating flora by at least ten to one. When the proportion is less than this the significance of Esch. coli and other species even when present in numbers approximating to 100,000 per $\mathrm{ml}$. must be regarded as doubtful.

4. No estimation to establish significant bacteriuria can be carried out in the presence of antibacterial substances in the urine. This is such a frequent occurrence in specimens sent to the laboratory that routine assay should be carried out on all specimens of urine at the time of culture.

5. All results must be interpreted in the light of methods of sampling of the specimen, and the time interval elapsing between sampling and examination, as well as previous knowledge of the case if any.

\section{Present Series}

Eight hundred and ninety-three cases have been examined in this way, and represent consecutive patients presenting themselves at the ante-natal clinic of an Edinburgh maternity hospital. On the basis of at least two pre-treatment urine bacteriological examinations, those patients with significant bacteriuria were allocated at random to a course of treatment with sulphadimidine, $1 \mathrm{~g}$. three times a day, or ampicillin 0.25 g., four times a day, each for 14 days. Further urine specimens were taken at the end of this course of treatment, and at two- or fourweekly intervals thereafter until delivery of the child. A number of cases have also been followed up at post-natal clinics.

Of 893 consecutive patients examined, over a three month period, $55(6.2 \%)$ were
TABLE II

Antibiograms of Strains Isolated from the Present Series.

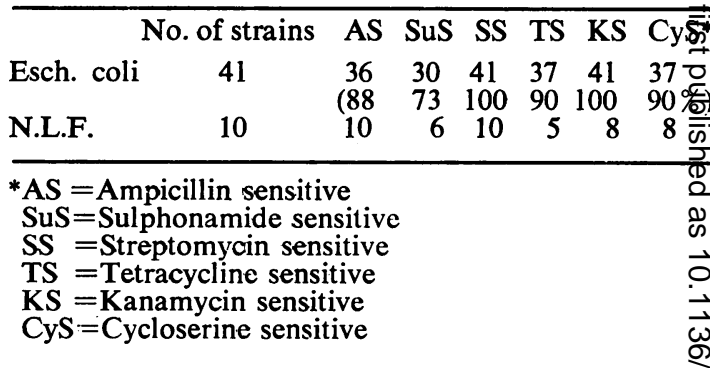

found to have a significant bacteriuria with the types of flora as shown in Table I, which conform to those most commonly isolate from this type of case. The predominance of Esch. coli will be noted. (Table I).

Determination of the antibiotic sensitivity this flora is of interest since it shows that the majority of the coliforms were sensitive to bow ampicillin and sulphonamide, as well as to most of the other antibiotics tested (Table IIg.

Further, these figures correspond ver closely to the antibiograms of 1,000 strains of coliforms isolated from cases of urination tract infection contracted outside of hospetat which we have studied during the previous $\leq 100$ months, but are in marked contrast to the strains isolated from hospital contracted urinary tract infections where the majorit of strains are resistant to both sulphonamidess and tetracyclines.

A limited number of coccal strains which were isolated proved to be both sulphonamide and ampicillin resistant in vitro, but this does not conform to our general findings, as two thinds of the strains of Streptococcus facalts isolated from urinary tract infections have been ampicillin-sensitive and only a minorit resistant to sulphonamide.

Of some importance is the level of sensitivity which is taken to divide the "sensitive" from the "resistant" strains. Shown in Table II is the more detailed sensitivity of the coliform bacilli isolated in the present series to bot sulphonamide and ampicillin. All of the strains were sensitive to amounts of ampicillit less than the average amount found in the urine following $0.25 \mathrm{~g}$. four times a day, but is this the standard to go by? Is it not more correct te๊ be guided by the average plasma level of the antibiotic, e.g. $5 \mu \mathrm{g} . / \mathrm{ml}$.? Ninety per cent $\sigma^{9}$ our strains were sensitive to less than $25 \mu \mathrm{g} . / \mathrm{m}$ and $78 \%$ to less than $5 \mu \mathrm{g} . / \mathrm{ml}$. Further what kind of in vitro tests should be used 
TABLE III

Results of Treatment

\begin{tabular}{|c|c|c|c|}
\hline & Total & $\begin{array}{l}\text { Number of Patients } \\
\text { Sulphadimidine } \\
1 \text { g. t.i.d }\end{array}$ & $\begin{array}{l}\text { Treated with } \\
\text { Ampicillin } \\
0.25 \text { q.i.d. }\end{array}$ \\
\hline & 45 & 24 & 21 \\
\hline $\begin{array}{l}\text { Success } \\
\text { Failure }\end{array}$ & 32 & 14 & 18 \\
\hline Failure & 13 & 10 & 3 \\
\hline
\end{tabular}

10 withdrawals, including 1 because of sulphonamide toxicity and 1 of ampicillin hypersensitivity

We have carried out both plate diffusion and serial dilution tube tests and found them to correlate reasonably well: however, by using very heavy inocula in both types of test and the replioa plate technique following initial diffusion plate tests, it has been possible to show the presence of ampicillin-resistant mutants occurring in a number of strains, but so far their appearance has not been correlated with failure of treatment.

In the case of the sulphonamides there is perhaps greater reason to question our interpretation of the in vitro tests: these are difficult to carry out by serial dilution tests and we have relied entirely upon diffusion plate studies, but our level of $100 \mu \mathrm{g}$. $/ \mathrm{ml}$. may be too high; thus, taking $25 \mu \mathrm{g} . / \mathrm{ml}$. as the critical level of sensitivity the proportion of sensitive strains would be considerably reduced and this would correlate better with the results of therapy.

\section{Results}

The results of treatment are shown in Table III and indicate that in the majority of the treated cases infection was suppressed following cessation of therapy and during the follow-up period which has not been less than three months in any case. Ampicillin has been more effective in this respect than sulphadimidine, although the series is as yet rather small to draw outright conclusions. Failure in the ampicillin cases may have been due to relative ampicillin resistance and in one case is correlated with the presence of small num-
TABLE IV

Relationship of Antibiotic Sensitivity to Results of Treatment

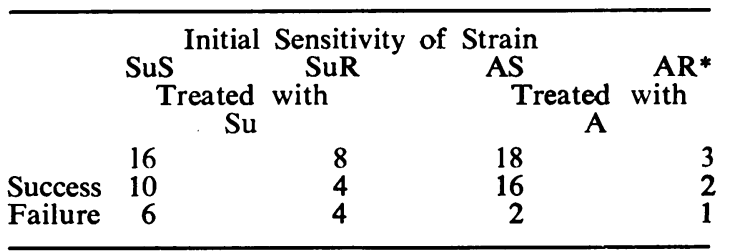
*Su=Sulphonamide
$\mathrm{A}=$-Ampicillin
1 failure associated with change $\mathrm{SuS} \rightarrow \mathrm{SuR}$

$\mathbf{S}=$ sensitive $\mathbf{R}=$ resistant

In no other case of failure was there any change in sensitivity

bers of resistant mutants in the original population although significant resistance after treatment was not measured. Failure in the sulphonamide treated oases was due in four instances to relatively high sulphonamide resistance but not to any known cause in the remaining cases (Table IV). In one patient the original sulphonamide-sensitive population was replaced by a sulphonamide-resistant population, presumably by selection. However, the bacteriological result of therapy could not be absolutely related to in vitro sensitivity.

\section{Summary}

Care is required in the diagnosis of urinary tract infection particularly in the young female where there may be difficulty in distinguishing relatively heavy growths of skin and vaginal contaminating flora. A quantitative method is necessary and must be supported by full qualitative analyses including estimation of antibacterial products in the urine.

Treatment with sulphonamide and ampicillin has shown the latter to be more effective in the elimination of the bacteria normally found in early urinary tract infections: this may be related to the relative resistance of the infecting bacteria to sulphonamide in concentrations normally found in the plasma as opposed to the more usually accepted urine concentrations. 